\title{
PEMBERDAYAAN KADER POSYANDU MELALUI PENINGKATAN PENGETAHUAN DETEKSI DINI IBU HAMIL RISIKO TINGGI DAN KETRAMPILAN PENGUKURAN TEKANAN DARAH DAN LINGKAR LENGAN ATAS DI KELURAHAN TEJOSARI KECAMATAN METRO TIMUR
}

\author{
Riyanto, Islamiyati, Herlina \\ Prodi Kebidanan Metro, Politeknik Kesehatan Tanjungkarang Lampung \\ Coresponding Author, Email: riyanto@poltekkes-tjk.ac.id
}

\begin{abstract}
High risk of pregnant women is a condition of pregnancy that can lead to the danger of possible complications in pregnant women, even the death of the mother during childbirth and the fetus. The results of a preliminary study on Posyandu cadres in Tejosari sub-district, Metro city of 16 active cadres, still lack the ability of cadres to recognize high risk of pregnancy. Efforts made by empowerment through cadre training with the aim of community service are to increase the knowledge of Posyandu cadres about early detection of high-risk pregnant women with the Poedji Rockjati score card approach (KSPR) and improve blood pressure measurement skills and upper arm circumference. Cadre empowerment activities are carried out using lectures, discussions, small group discussions and skill practice with simulations. The results of community service activities show that there is an increase in knowledge from the average pre-test measurement of 69.67 to 82.40 on the post-test measurement and basic skills of cadres after training in measuring blood pressure from the average observation results that all are quite good and for upper arm circumference measurement skills Everything is fine. The conclusion is that the empowerment of Posyandu cadres increases knowledge and skills regarding early detection of high-risk pregnant women. It is necessary to monitor the ability of cadres directly to pregnant women in carrying out educational functions.
\end{abstract}

Keywords: Posyandu cadres; High risk pregnant women; Knowledge; Blood pressure measurement.

Abstrak

Risiko tinggi ibu hamil merupakan keadaan kehamilan yang dapat mengakibatkan bahaya kemungkinan terjadi komplikasi pada ibu hamil, bahkan kematian ibu saat melahirkan dan janin. Hasil studi pendahuluan pada kader Posyandu di kelurahan Tejosari kota Metro dari 16 kader yang aktif masih kurangnya kemampuan kader mengenali risiko tinggi kehamilan. Upaya yang dilakukan dengan pemberdayaan melalui pelatihan kader dengan tujuan PKM adalah meningkatkan pengetahuan kader Posyandu tentang deteksi dini ibu hamil risiko tinggi dengan pendekatan kartu skor poedji rockjati (KSPR) dan meningkatkan ketrampilan pengukuran tekanan darah dan LILA. Kegiatan pemberdayaan kader dilakukan dengan metode ceramah, diskusi, small group discussion dan praktik ketrampilan dengan simulasi. Hasil kegiatan PKM menunjukkan terdapat peningkatan pengetahuan dari rata-rata pengukuran pre test 69,67 menjadi 82,40 pada pengukuran post test dan ketrampilan dasar kader setelah pelatihan pengukuran tekanan darah dari hasil observasi rata-rata semua cukup baik dan untuk ketrampilan pengukuran LILA diperoleh hasil semua baik. Kesimpulan bahwa pemberdayaan kader Posyandu terjadi peningkatan pengetahuan dan ketrampilan tentang deteksi dini ibu hamil risiko tinggi. Perlu dilakukan pemantauan kemampuan kader langsung ke ibu hamil dalam melakukan fungsi edukasi.

Kata kunci: Kader posyandu; Ibu hamil risiko tinggi; Pengetahuan; Pengukuran tekanan darah.

(C) 2020 Penerbit PS2PM FISIPKUM UNSERA

(C) 2020 Segala bentuk plagiarisme dan penyalahgunaan hak kekayaan intelektual akibat diterbitkannya artikel pengabdian masyarakat ini sepenuhnya menjadi tanggung jawab penulis

Riyanto, Islamiyati, Herlina. Pemberdayaan Kader Posyandu melalui Peningkatan Pengetahuan Deteksi Dini Ibu Hamil Risiko Tinggi dan Ketrampilan Pengukuran Tekanan Darah dan Lingkar Lengan Atas di Kelurahan

Tejosari Kecamatan Metro Timur.

Halaman 98-109 


\section{Pendahuluan}

Pemberdayaan

masyarakat

bidang kesehatan merupakan proses untuk meningkatkan pengetahuan, kesadaran dan kemampuan individu, keluarga serta masyarakat untuk berperan aktif dalam upaya kesehatan yang dilaksanakan dengan cara fasilitasi proses pemecahan masalah melalui pendekatan edukatif dan partisipatif serta memperhatikan kebutuhan potensi dan sosial budaya setempat (Kemenkes RI, 2019).

Bentuk pemberdayaan masyarakat bidang kesehatan salah satunya adalah peran kader Posyandu. Posyandu merupakan salah satu bentuk Upaya Kesehatan Bersumber Daya Masyarakat (UKBM) yang dikelola dan diselenggarakan dari, oleh, untuk dan bersama masyarakat dalam penyelenggaraan pembangunan kesehatan, guna memberdayakan masyarakat dan memberikan kemudahan kepada masyarakat dalam memperoleh pelayanan kesehatan dasar, utamanya untuk mempercepat penurunan angka kematian ibu dan bayi (Kemenkes, 2011).

Jumlah kasus kematian ibu melahirkan di Kota Metro tahun 2015 tidak ada kematian dan tahun 2016 tejadi kematian 2 dari 2740 kelahiran hidup (diperkirakan 73 per $100.000 \mathrm{KH}$ ), sedangkan tahun 2017 meningkat menjadi 3 kematian dari 2786 kelahiran hidup (diperkirakan 107,7 per 100.000 KH) (Dinkes kota Metro, 2018). Sedangkan, angka kematian ibu di Provinsi lampung tahun 2016 disebabkan oleh perdarahan sebanyak 45 kasus, hipertensi sebanyak 41 kasus, infeksi sebanyak 1 kasus, ganguan sistem peredaran darah sebanyak 8 kasus, gangguan metabolik sebanyak 0 kasus. Data kematian tersebut sulit untuk dibandingkan tinggi rendahnya, karena masih angka absolut (Dinkes Provinsi Lampung, 2017).

Penyebab tingginya angka kematian ibu diantarnya adalah kehamilan risiko tinggi yang tidak 
terdeteksi, termasuk hipertensi pada ibu hamil. Pentingnya upaya melakukan pemeriksaan kehamilan yang bertujuan untuk medeteksi kemungkinan adanya risiko-risiko yang timbul dalam kehamilan (Wiknjosastro, 2006). Alat bantu dalam melakukan deteksi dini ibu hamil dapat menggunakan lembar Kartu Skor Poedji Rochjati. Hasil penelitian Saraswati \& Hariastuti (2017) menunjukkan Kartu Skor Poedji Rochjati (KSPR) efektif untuk deteksi resiko tinggi pada ibu hamil (p-value 0,001). KSPR ini dapat digunakan oleh tenaga kesehatan, kader posyandu, dukun, suami, dan keluarga yang telah dibekali dengan pengetahuan dan keterampilan dalam menggunakannya (Rochjati, 2011).

Kader posyandu bagian dari anggota masyarakat yang paling dekat dengan warga masyarakat, sehingga ia lebih mengenal masalah dan perubahan yang terjadi di wilayahnya. Ia melakukan tugasnya dengan menemukan ibu hamil lebih cepat,

bahkan dari tenaga kesehatan. Selain itu, mampu mengetahui faktor risiko yang dialami ibu hamil yang menyertainya. Namun, kader perlu dibekali dengan pengetahuan dan ketrampilan. Pemerintah dalam hal ini Kementerian Kesehatan membuat kebijakan mengenai pelatihan untuk kader yang bertujuan untuk meningkatkan pengetahuan, menurunkan angka kemtian ibu dan angka kematian bayi (Meilani, Setiyawati, \& Estiwidani, 2013). Sehingga, Peran kader sangat penting untuk mengenali masalah dan deteksi dini ibu hamil risiko tinggi, karena saat ini peran dan tugas kader di kota Metro masih pada kegitaan lima meja, perlu peran tambahan khususnya dalam deteksi dini ibu hamil risiko tinggi untuk meningkatkan pemberdayaan kader Posyandu.

Kader Posyandu di kelurahan Tejosari terdiri atas 4 Posyandu yang aktif 15 orang dari 20 kader yang dipilih. Belum semua pernah mendapatkan pelatihan tentang pendampingan 
penggunaan buku KIA dan kemampuan mendeteksi dini ibu hamil berisiko tinggi masih rendah. Untuk itu, perlu dicari solusi dengan memberdayakan kader Posyandu melalui penyuluhan kesehatan dan pelatihan yang dapat meningkatkan pengetahuan kader Posyandu dan ketrampilan deteksi dini ibu hamil risiko tinggi menggunakan KSPR. KSPR sudah sejak tahun 2004 dimasukkan sebagai media edukasi di buku KIA provinsi Jawa Timur, namun belum di buku KIA provinsi Lampung maupun kota Metro. PKM bertujuan untuk peningkatan pengetahuan dan ketrampilan dasar kader Posyandu dengan pengukuran tekanan darah dan LILA untuk deteksi dini risiko tinggi ibu hamil.

\section{Metode Pelaksanaan}

Kegiatan pengabdian masyarakat (PKM) dengan pemberdayaan kader Posyandu dalam deteksi dini risiko ibu hamil dilaksanakan di kelurahan Tejosari kecamatan Metro Timur kota
Metro yang merupakan salah satu desa atau kelurahan binaan Poltekkes Tanjungkarang Prodi Kebidanan Metro tahun 2018. Jumlah sampel atau sasaran PKM adalah kader Posyandu yang diambil dengan teknik total sampling didapatkan 15 orang kader aktif dari 4 kader Posyandu. Kegiatan PKM ini bertujuan untuk memberikan kemampuan tambahan (pemberdayaan), selain kemampuan dasar kepada kader Posyandu dengan peningkatan pengetahuan dan ketrampilan deteksi dini ibu hamil risiko tinggi. Peningkatan ketrampilan pengukuran tekanan darah dan pengukuran lingkar lengan atas (LILA) sudah menjadi bagian ketrampilan dasar bagi kader di komunitas. Metode PKM dalam pemberdayaan kader posyandu dilakukan dengan tahapan pembuatan modul deteksi dini risiko ibu hamil dengan menggunakan KSPR, penyuluhan kesehatan, small group discusion, praktikum oleh Tim dan 
simulasi ketrampilan oleh kader Posyandu.

Pelaksanaan kegiatan PKM di kelurahan Tejosari kecamatan Metro Timur kota Metro dengan metode :

1. Penyuluhan kesehatan dengan ceramah dan tanya jawab tentang deteksi dini risiko ibu hamil dengan menggunakan KSPR;

2. Small group discusion tentang masalah riil pada ibu hamil dengan risiko tinggi dan mengisi KSPR;

3. Pelatihan pengisian skor poedji rochjati, praktikum pengukuran tekanan darah dan LILA dalam rangka peningkatan ketrampilan dasar tambahan untuk pemberdayaan kader Posyandu;

4. Simulasi kembali oleh kader Posyandu ketrampilan dasar pengukuran tekanan darah dan LILA. Keempat tahapan metode tersebut secara garis besar terdiri atas tahapan persiapan, pelaksanaan kegiatan dan evaluasi. Tahap persiapan, Tim merumuskan perencanaan dalam

bentuk schedule kegiatan agar pengabdian terprogram dan target kegiatan mudah terukur. Tim melakukan koordinasi dengan pihak mitra pengabdian meliputi Puskesmas setempat untuk mendapatkan perizinan, setelah sebelumnya ada MoU dengan Dinas Kesehatan kota Metro. Bersama pihak Puskesmas dan Bidan Poskeskel melakukan penjajakan masalah yang ada pada peran dan tugas kader. Persiapan dan kesepakatan waktu dan tempat kegiatan pengabdian berkoordinasi dengan Lurah, Bidan di Poskeskes dan kader Posyandu.

Tahap pelaksanaan kegiatan pengabdian, tim memberikan penyuluhan kesehatan dan pelatihan dilaksanakan pada tanggal 25 dan 26 Juni 2020 di Pos Kesehatan Kelurahan. Pemberdayaan kader Posyandu oleh TIM PKM dilakukan dengan kegiatan awal mengukur pengetahuan kader tentang deteksi dini risiko tinggi ibu hamil menggunakan pendekatan KSPR (pre test). Kuesioner dikembangkan dari 
KSPR terkait deteksi dini risiko tinggi ibu hamil (Rochjati, 2011).

Akhir tahap kegiatan pengabdian, tim melakukan evaluasi untuk mengetahui dampak kegiatan terhadap pengetahuan dan kemampuan kader Posyandu dalam deteksi dini risiko tinggi ibu hamil. Evaluasi dilakukan dengan pengisian kembali kuesioner (post test) (sebelum diberikan penyuluhan kesehatan dan post test (setelah penyuluhan). Sedangkan, ketrampilan pengukuran tekanan darah dan LILA menggunakan metode observasi. Hasil post test dibandingkan dengan pre test yang dianalisis menggunakan analisis univariat dengan distribusi frekuensi.

\section{Hasil dan Pembahasan}

Kelurahan Tejosari merupakan salah satu kelurahan di kecamatan Metro Timur kota Metro dari wilayah kerja Puskesmas Tejoagung Metro Timur yang salah satu desa/ kelurahan binaan Poltekkes Tanjungkarang dengan Tim Pelaksana Prodi Kebidanan Metro tahun 2018. Kelurahan Tejosari mempunyai 4 Posyandu. Setiap posyandu mempunyai kader masingmasing 5 orang, namun yang aktif 16 kader dari 20 kader. Namun, dalam kegiatan PKM yang berpartisipasi hanya 15 kader. Pelaksanaan kegiatan PKM di ruang Pos Kesehatan Kelurahan Tejosari.

Hasil kegiatan PKM memperoleh dua hasil, yaitu pengukuran pengetahuan dalam deteksi dini risiko tinggi ibu hamil dan ketrampilan dasar pengukuran tekanan darah dan LILA bagi kader Posyandu di kelurahan Tejosari kecamatan Metro Timur kota Metro. Pemberdayaan melalui pelatihan diperoleh pengetahuan kader Posyandu dalam deteksi dini risiko tinggi ibu hamil menggunakan pendekatan KSPR menunjukkan terdapat peningkatan dari rata-rata pengukuran pre test 69,67 menjadi 82,40 pada pengukuran post test atau selisih peningkatan pengetahuan 
dengan skor 12,76 dengan nilai terendah 66 dan tertinggi 100 (Tabel 1).

Hasil PKM ini sesuai dengan hasil penelitian Saraswati \& Hariastuti (2017) menunjukkan Kartu Skor Poedji Rochjati (KSPR) efektif untuk deteksi resiko tinggi pada ibu hamil (p-value 0,001). Oleh karena itu, KSPR ini dapat digunakan tidak hanya oleh tenaga kesehatan, tapi juga kader posyandu, dukun, suami, dan keluarga yang telah dibekali dengan pengetahuan dan keterampilan dalam menggunakannya (Rochjati, 2011).

Hasil peningkatan pengetahuan kader kemungkinan disebabkan adanya

pelaksanaan kegiatan PKM berjalan dengan lancar sesuai dengan rencana dan metode edukasi dengan ceramah dan tanya jawab atau diskuis yang menarik. Para kader antusias dan partisipasi sangat baik dengan aktif berdiskusi materi yang disampaikan dan aktif semua mengisi KSPR yang berisi keadaan ibu hamil dengan risiko tinggi. Selain itu, adanya dukungan dan keterlibatan pihak terkait yang langsung hadir dalam kegiatan PKM meliputi: perwakilan dari Puskesmas Tejoagung, Bidan Koordinator dan Bidan Pelaksana, Bidan Poskeskel dan Pengelola Posyandu.

Tabel 1.

Pengetahuan Kader Posyandu Pre Test dan Post test dalam Deteksi Dini Risiko Tinggi Ibu hamil di Kelurahan Tejosari Kecamatan Metro Timur Kota Metro

\begin{tabular}{lccc}
\hline Pengetahuan kader posyandu (n=15) & Rata-rata & Standar Deviasi & Mak-Min \\
\hline Sebelum (Pre Test) & 69,67 & 15,37 & $33-86$ \\
Sesudah (Post test) & 82,40 & 8,68 & $66-100$ \\
\hline
\end{tabular}

Tabel 2.

Ketrampilan Dasar Kader Posyandu dalam Pengukuran Tekanan Darah dan LILA Setelah Pelatihan di Kelurahan Tejosari Kecamatan Metro Timur Kota Metro

\begin{tabular}{clcc}
\hline Ketrampilan Dasar Kader Posyandu & \multicolumn{1}{c}{ Kategori } & Frekuensi & Prosentase (\%) \\
\hline Pengukuran Tekanan Darah & Baik & 0 & 0 \\
& Cukup baik & 15 & 100 \\
& Kurang baik & 0 & 0 \\
Pengukuran LILA & Baik & 15 & 100 \\
& Cukup baik & 0 & 0 \\
& Kurang baik & 0 & 0 \\
\hline
\end{tabular}



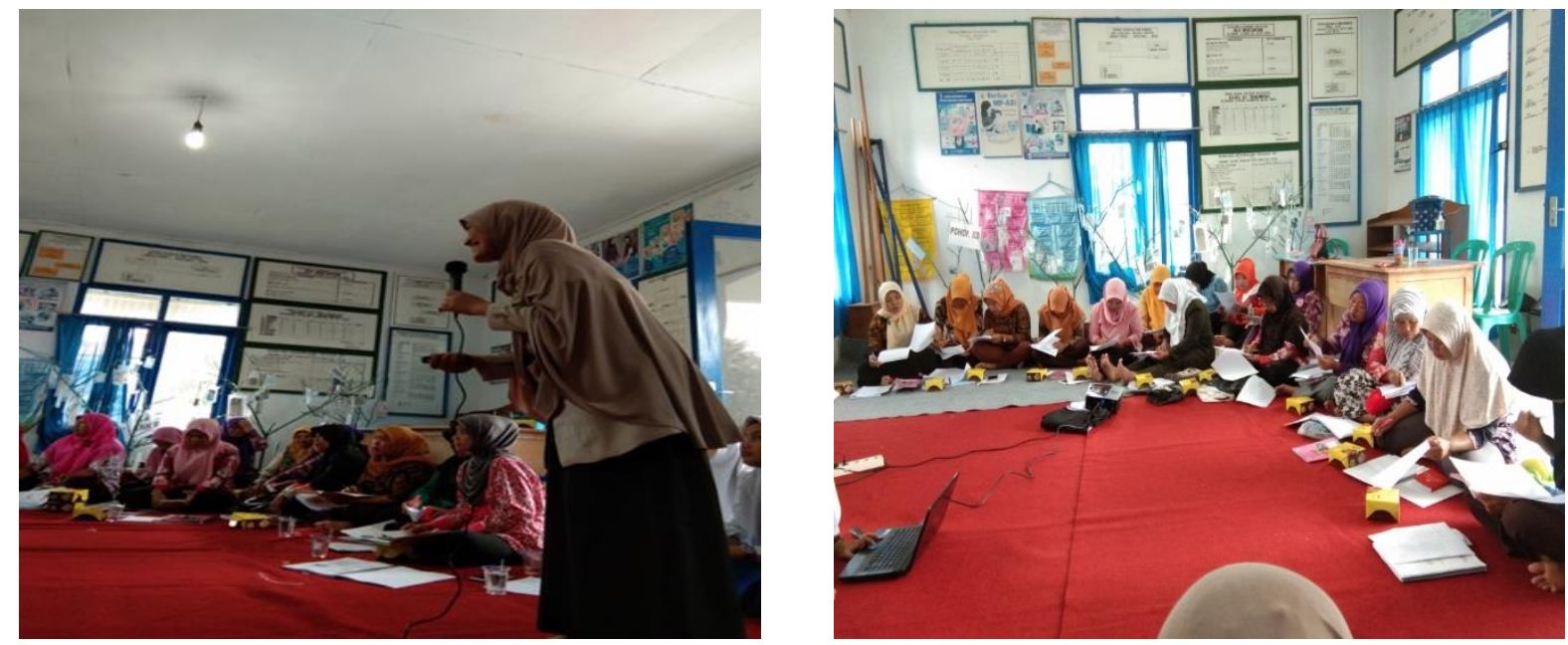

Gambar 1

Kegiatan Penyampaian Materi Deteksi Dini Kehamilan Risiko Tinggi dan Simulasi Pengisian KSPR
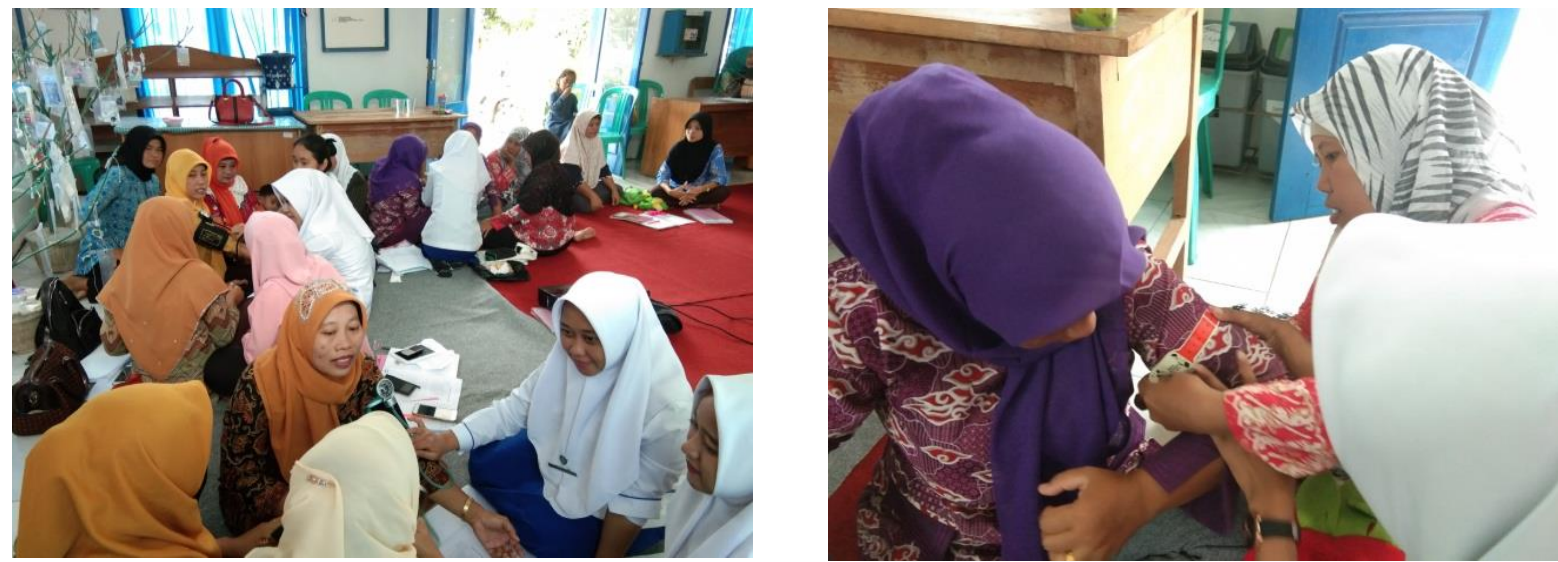

Gambar 2.

Simulasi Pendampingan Pengukuran Tekanan Darah dan Lingkar Lengan Atas oleh Kader Posyandu

Perubahan prilaku kesehatan pengetahuan, selain dua faktor, yaitu menurut Lawrence Green dalam faktor enabling atau faktor pemungkin Notoatmodjo (2012) pada individu dan faktor reinforcing atau faktor diantanya dipengaruhi faktor penguat. Maka, kegiatan PKM juga predisposing atau faktor yang melekat, memberikan pelatihan untuk salah stunya adalah tingkat meningkatkan kemampuan deteksi dini

Riyanto, Islamiyati, Herlina. Pemberdayaan Kader Posyandu melalui Peningkatan Pengetahuan Deteksi Dini Ibu Hamil Risiko Tinggi dan Ketrampilan Pengukuran Tekanan Darah dan Lingkar Lengan Atas di Kelurahan 
ibu hamil risiko tinggi bagi kader Posyandu, diharapkan Ia dapat berubah prilakunya untuk lebih aktif berperan memberikan edukasi kepada ibu hamil.

Hasil lain pemberdayaan kader Posyandu melalui pelatihan adalah meningkatkan ketrampilan kader posyandu. Ketrampilan dasar kader setelah pelatihan pengukuran tekanan darah dari hasil observasi rata-rata semua cukup baik dan untuk ketrampilan pengukuran LILA diperoleh hasil semua baik. Hasil PKM belum sampai melakukan kemampuan untuk interpretasi hasil pengukuran tekanan darah kategori normal, sedangkan menentukan darah tinggi dan rendah belum dilakukan (Tabel 2). Sesuai dengan hasil PKM oleh Anggraini, Merry, Mayasari \& Wijaya (2019) membuktikan bahwa kader Posyandu dengan pelatihan mampu meningkatkan kemampuan kader posyandu dalam melakukan deteksi dini kehamilan risiko tinggi.
Hasil PKM ini menunjukkan kader mampu ditingkatkan kemampuan ketrampilan psikomotornya. Kader setelah mendapatkan penyuluhan kesehatan, diberikan pelatihan pengukuran tekanan darah dan LILA dengan simulasi langsung oleh Tim PKM. Kader melakukan observasi, kemudian semua kader diberikan kesempatan melakukan kembali pengukuran tekanan darah dan LILA, serta terakhir dilakukan evaluasi.

Pemberdayaan masyarakat merupakan pilar 1 dalam penerapan paradigma sehat dalam mewujudkan Indonesia Sehat (Kemenkes RI, 2017). Pemberdayaan masyarakat merupakan strategi yang sudah terbukti memberikan kontribusi yang bermakna dalam peningkatan kualitas Sumber Daya Manusia (SDM) sebagai syarat utama dalam mendukung keberhasilan program pembangunan di Indonesia (Hermawan, \& Suryono, 2016). 
Posyandu merupakan institusi pemberdayaan masyarakat di bidang kesehatan dalam bentuk Upaya Kesehatan Bersumber Daya Masyarakat (UKBM) yang dikelola dan diselenggarakan dari, oleh, untuk dan bersama masyarakat dalam penyelenggaraan pembangunan kesehatan, guna memberdayakan masyarakat dan memberikan kemudahan kepada masyarakat dalam memperoleh pelayanan kesehatan dasar, utamanya untuk mempercepat penurunan angka kematian ibu dan bayi (Kemenkes, 2011). Artinya, Kader Posyandu sangat perlu diberdayakan seberapun kontribusinya.

Pemberdayaan kader posyandu untuk mengenal deteksi dini ibu hamil risiko tinggi perlu ditingkatkan dan dilakukan tindaklanjut dengan dimonitor dalam melakukan peran dan tugasnya, termasuk kemampuan mengukur tekanan darah pada ibu hamil untuk deteksi dini hipertensi pada kehamilan. Hipertensi pada ibu hamil yang merupakan salah satu penyebab kematian ibu. Selain itu, memotivasi dan edukasi untuk ibu hamil risiko tinggi untuk rutin melakukan antenatal care selama kehamilan baik di Puskesmas, Posyandu atau fasilitas pelayanan kesehatan lain yang mengalami risiko tinggi maupun tidak.

\section{Penutup}

Kegiatan PKM ini berdasarkan hasil dan pembahasan dapat disimpulkan bahwa pemberdayaan kader Posyandu melalui pelatihan dapat meningkatkan pengetahuan tentang deteksi dini ibu hamil risiko tinggi menggunakan KSPP dan memberikan kemampuan psikomotor ketrampilan pengukuran tekanan darah dan LILA. Kader Posyandu perlu diberikan kesempatan mengikuti pelatihan untuk meningkatkan pemberdayaananya di masyarakat dan dimonitor tugas dan perannya setelah kegiatan PKM ini. 


\section{Ucapan Terima Kasih}

Ucapan terima kasih kami haturkan kepada Politeknik Kesehatan Tanjungkarang yang telah mendanai kegiatan PKM ini dan Puskesmas Tejoagung yang telah memberikan izin, Lurah dan para Kader Posyandu kelurahan Tejosari yang telah memfasilitasi dan berpartisipasi, sehingga kegiatan berjalan dengan lancar dan baik.

\section{Referensi}

Angraini, D. I., Merry, I. S., Mayasari, D. M., \& Sofyan Mussabiq Wijaya, S. M. W. (2019). (2019). Pelatihan kader posyandu dalam deteksi dini ibu hamil risiko tinggi (Risti) di Puskesmas Karang Anyar Kabupaten Lampung Selatan. JPM Ruwa Jurai, 4(1), 13-17. http://repository.lppm.unila.ac.id/i d/eprint/25225

Dinkes Kota Metro (2018). Profil kesehatan kota Metro tahun 2017. Metro: Dinkes kota Metro.
Dinkes Provinsi Lampung (2017). Profil kesehatan provinsi Lampung tahun 2016. Bandarlampung: Dinkes Provinsi Lampung.

Hermawan, Y., \& Suryono, Y. (2016). Partisipasi masyarakat dalam penyelenggaraan

programprogram pusat kegiatan belajar masyarakat Ngudi Kapinteran. Jurnal Pendidikan dan Pemberdayaan Masyarakat. 3(1). 97108.

DOI:

https://doi.org/10.21831/jppm.v3i1. 8111

Kemenkes RI (2019). Permenkes No. 8 tahun 2019 tentang pemberdayaan masyarakat bidang kesehatan. Jakarta: Kemenkes RI.

Kemenkes RI. (2017). Germas - Gerakan Masyarakat Hidup Sehat. Retreived from https://promkes.kemkes.go.id/ger mas

Kemenkes RI (2011). Pedoman uтum pengelolaan posyandu. Jakarta: Kemenkes RI 
Meilani, N., Setiyawati, N., \& Saraswati, D. E., \& Hariastuti, F. P. Estiwidani, D. (2013). Kebidanan (2017). Efektivitas kartu skor Poedji komunitas. Yogyakarta: Fitramaya. Rochjati (KSPR) untuk deteksi Notoatmodjo, S. (2012). Ilmu Prilaku Kesehatan. Jakarta: Rineka Putra. resiko tinggi pada ibu hamil di Puskesmas Ngumpakdalem Rochjati P. (2011). Skrinning antenatal pada ibu hamil pengenalan faktor Kabupaten Bojonegoro. Jurnal Ilmu Kesehatan MAKIA, 5(1), 28-33. risiko. Surabaya: Airlangga University Press. Wiknjosastro (2006). Ilmu kebidanan. Edisi Ketiga. Jakarta: Yayasan Bina Pustaka Sarwono Prawirohardjo. 